\title{
Quando as fundações tremem: Ontologia e antropologia na teologia da revelação de Paul Tilich
}

Orientador: Lúcia Pedrosa de Pádua

Mestrando: Elielson Macedo Feliciano

Área de Concentração: Teologia Sistemático-Pastoral

Linha de Pesquisa: Religião e Modernidade

Esta pesquisa tem por objetivo buscar, na Teologia Sistemática de Paul Tillich, os fundamentos ontológicos e antropológicos da revelação. O caráter "especial e extraordinário" da revelação faz dela objeto da discussão teológica sobre as vias do conhecimento, se a natural ou a supranatural. O método da correlação de Tillich oferece uma alternativa ao enfrentamento da questão, fazendo de sua teologia uma obra de teologia fundamental, ou, como ele preferia dizer, uma teologia apologética.

Palavras-chave: Teologia apologética; Método da correlação; Teologia Sistemática; Paul Tillich; Ontologia; Antropologia. 